INTEGRITAS : Jurnal Pengabdian

Vol 4, No 2, Desember 2020

ISSN $2580-7978$ (cetak) ISSN 2615 - 0794 (online)

\title{
PEMBUATAN ALAT CUCI TANGAN MOBILE DALAM PENCEGAHAN CORONA VIRUS PADA TEMPAT IBADAH
}

\section{MAKING OF MOBILE WASHERS IN PREVENTION OF CORONA VIRUSES IN WORSHIP}

\author{
Romadhoni $^{1)}$, Budhi Santoso ${ }^{2)}$, Muhammad Helmi ${ }^{3)}$ \\ ${ }^{123}$ Politeknik Negeri Bengkalis \\ ${ }^{1}$ Email: romadhoni@polbeng.ac.id
}

\begin{abstract}
Abstrak: Setiap orang atau individu dapat melindungi diri dari serangan virus corona, salah satunya dengan rajin membersihkan tangan dengan sabun atau hand sanitizer. Ahli kesehatan menganjurkan untuk mencuci tangan dengan sabun dan air mengalir selama 1530 detik. Pusat Pengendalian dan Pencegahan Penyakit (CDC) menganjurkan perbanyak busa saat mencuci tangan dengan sabun karena gesekannya dapat membantu mengangkat kotoran dan minyak dari kulit. CDC merekomendasikan beberapa waktu yang tepat untuk mencuci tangan di antaranya sebelum, selama, dan sesudah memasak, sebelum makan, sebelum dan sesudah merawat luka dan orang sakit, setelah menggunakan toilet, setelah mengganti popok, setelah memegang hewan atau makanan hewan, setelah menyentuh atau membuang sampah, sesudah bersin, batuk, atau menyeka hidung, dan setelah berjabat tangan. Untuk memfasilitasi masyarakat dalam menjaga kebersihan dengan mencuci tangan, maka perlu di desain dan bangun sebuah alat cuci tangan yang mobile atau bisa di pindah-pindah serta kapasitas tangki yang besar serta beberapa krain air agar masyarakat tidak antri dalam mencuci tangan. Alat cuci tangan ini dinamakan mobile hand washer (MHW) atau wastafel portable. Alat ini akan didistribusikan ke berbagai tempat pelayanan publik yang diantaranya seperiti rumah ibadah, pelabuhan penyebranagan, hingga tempat-tempat umumnya ada keramaian atau pelayanan publik yang tidak lockdown di wilayah Kabupaten Bengkalis.
\end{abstract}

Kata Kunci: cuci tangan, mobile, MHW

Abstract Every person or individual can protect themselves from corona virus attacks, one of which is to diligently clean their hands with soap or hand sanitizer. Health experts recommend washing your hands with soap and running water for 15-30 seconds. The Centers for Disease Control and Prevention $(C D C)$ recommends increasing foam when washing hands with soap because its friction can help remove dirt and oil from the skin. The CDC recommends the right time to wash your hands before, during and after cooking, before eating, before and after treating wounds and sick people, after using the toilet, after changing diapers, after handling animals or animal food, after touching or disposing rubbish, after sneezing, coughing, or wiping the nose, and after shaking hands. To facilitate the community in maintaining cleanliness by washing hands, it is necessary to design and build a mobile hand washing device that can be moved as well as a large capacity tank and some water drains so that people do not queue in washing hands. This hand washing tool is called a mobile hand washer $(M H W)$ or portable sink. This tool will be distributed to various public service places, such as places of worship, 
INTEGRITAS : Jurnal Pengabdian

Vol 4, No 2, Desember 2020

ISSN 2580 - 7978 (cetak) ISSN 2615 - 0794 (online)

ports of harbor, to places where there is generally a crowd or public services

that are not lockdown in Bengkalis Regency.

Keywords: hand washing, mobile, $M H W$

\section{PENDAHULUAN}

Wabah penyakit coronavirus (COVID-19) ditetapkan sebagai Kedaruratan Kesehatan Masyarakat yang Meresahkan Dunia (PHEIC) dan virusnya sekarang sudah menyebar ke berbagai negara dan teritori. Memang masih banyak yang belum diketahui tentang virus penyebab COVID-19, tetapi kita tahu bahwa virus ini ditularkan melalui kontak langsung dengan percikan dari saluran napas orang yang terinfeksi (yang keluar melalui batuk dan bersin). Orang juga dapat terinfeksi karena menyentuh permukaan yang terkontaminasi virus ini lalu menyentuh wajahnya (mis., mata, hidung, mulut). Meskipun COVID-19 terus menyebar, masyarakat harus mengambil tindakan untuk mencegah penularan lebih jauh, mengurangi dampak wabah ini dan mendukung langkah-langkah untuk mengendalikan penyakit ini.

Setiap orang atau individu dapat melindungi diri dari serangan virus corona, salah satunya dengan rajin membersihkan tangan dengan sabun atau hand sanitizer. Ahli kesehatan menganjurkan untuk mencuci tangan dengan sabun dan air mengalir selama 15-30 detik. Pusat Pengendalian dan Pencegahan Penyakit (CDC) menganjurkan perbanyak busa saat mencuci tangan dengan sabun karena gesekannya dapat membantu mengangkat kotoran dan minyak dari kulit.

Untuk memfasilitasi masyarakat dalam menjaga kebersihan dengan mencuci tangan, maka perlu di desain dan bangun sebuah alat cuci tangan yang mobile atau bisa di pindah-pindah serta kapasitas tangki yang besar serta beberapa krain air agar masyarakat tidak antri dalam mencuci tangan. Alat cuci tangan ini dinamakan mobile hand washer (MHW) atau wastafel portable. Alat ini akan didistribusikan ke berbagai tempat pelayanan publik yang diantaranya seperiti rumah ibadah, pelabuhan penyebranagan, hingga tempat-tempat umumnya ada keramaian atau pelayanan publik yang tidak lockdown di wilayah Kabupaten Bengkalis. 


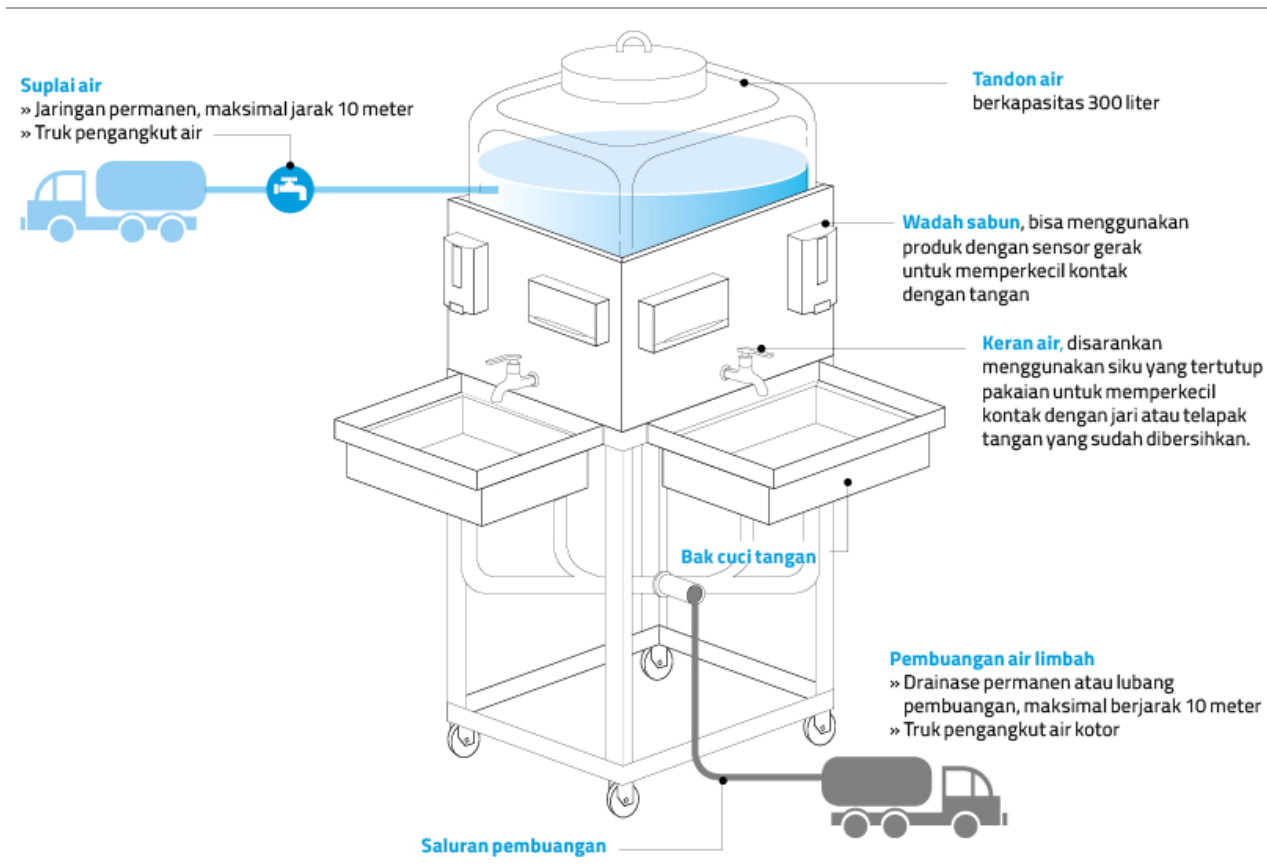

Gambar 1. Alat Cuci Tangan Portable

Produk Alat ini yaitu mobile hand washer (MHW) dirancang agar mudah di dorong dengan tenaga manusia agar bisa di pindahkan sesuai keinginan, alat cuci tangan ini juga menjdi alternatif solusi dalam kondisi darurat di tempat umum atau pelayanan publik, dimana banyak masyarakat yang berinteraksi. Alat ini di lengkapi dengan empat buah bak pencuci tangan atau westafel, yang di kelilingi tandon air kapasitas 250 Liter dengan jarak sesuai dengan aturan kesehatan dunia (WHO) yaitu 1 meter. Untuk mengisi alat ini bisa mengunakan pasokan air dari jaringan yang sudah ada atau mengunakan pasokan dari mobil tanki air milik PDAM, dengan kontruksi besi hallow $2 \times 3 \mathrm{~cm}$ dengan sistem pembuatan yang terkonesi agar tidak menimbulkan penyakit lain. Dengan Desain dan Pembuatan alat ini diharapakan Politeknik Negeri Bengkalisdapat turut mendukung upaya pemerintah dalam mencegah penyebaran Covid-19 dan memberikan solusi nyata bagi kebutuhan masyarakat dalam menghadapi pandemi Covid-19 
INTEGRITAS : Jurnal Pengabdian

Vol 4, No 2, Desember 2020

ISSN 2580 - 7978 (cetak) ISSN 2615 - 0794 (online)

\section{METODE}

Diagram alir Program Pengabdian Masyarakat untuk mencapai tujuan dalam pengabdian ini dapat dilihat pada gambar 2 berikut ini:

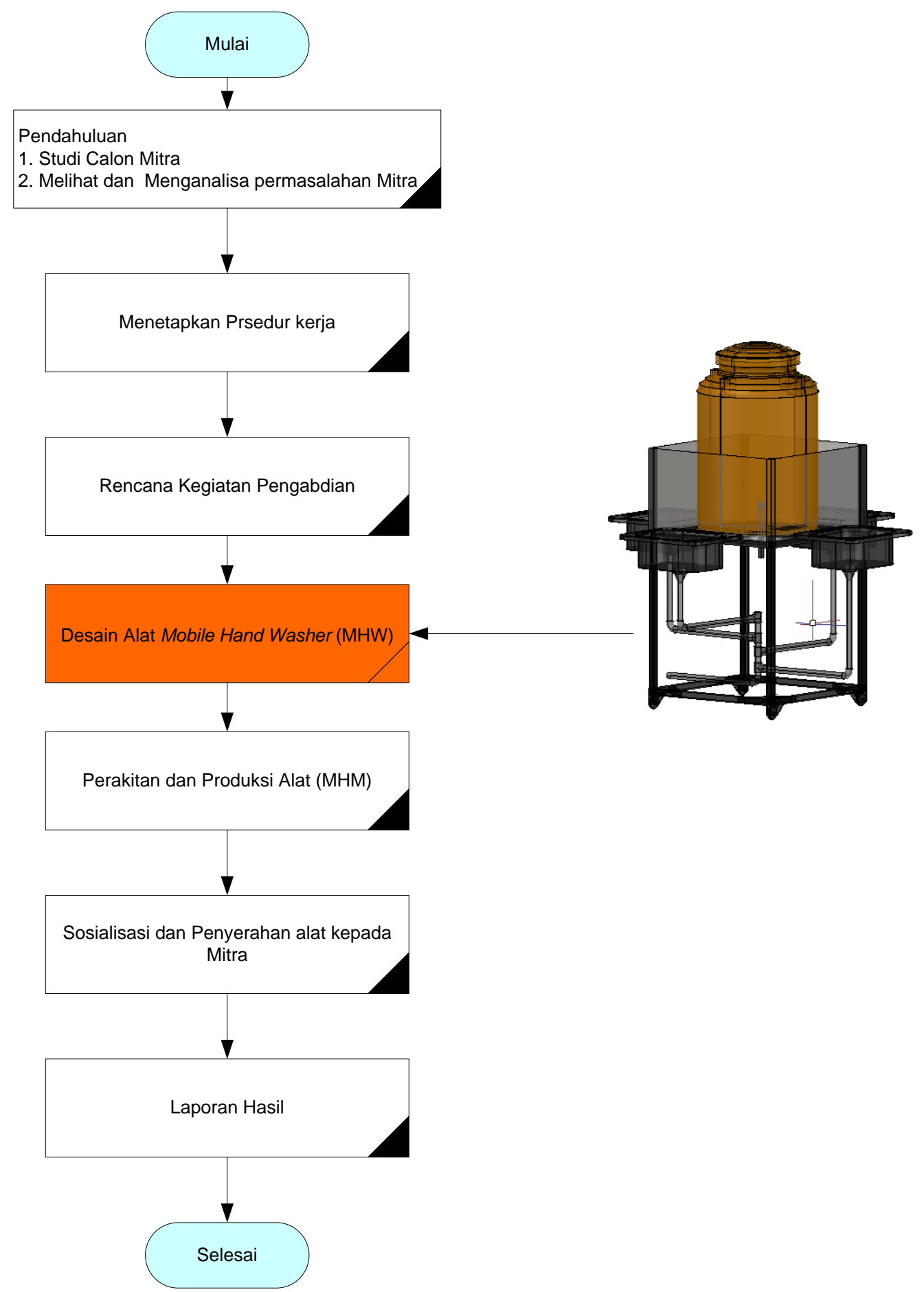

Gambar 2. Diagram Alir usulan Pengabdian Masyarakat PNBP POLBENG 
INTEGRITAS : Jurnal Pengabdian

Vol 4, No 2, Desember 2020

ISSN 2580 - 7978 (cetak) ISSN 2615 - 0794 (online)

\section{Menetapkan Prosedur Kerja}

Sebelum melaksanakan kegiatan perlu ditetapkan prosedur kerja dengan tujuan setiap kegiatan yang dilaksanakan terarah. Prosedur kerja diawali dengan menetapkan mitra kerja. Dalam hal ini mitra kerja akan diajak berdiskusi dan memberikan informasi tentang alat Mobile Hand Washer (MHW).

\section{Desain Alat}

Merupakan proses desain alat Mobile Hand Washer (MHW), hal ini dilakukan agar alat ini setelah di produksi dapat di gunakan kepada semua pihak.

\section{Perakitan dan Produksi Alat}

Proses perakitan dan produksi alat Mobile Hand Washer (MHW) dilakukan di bengkel las dan pipa Jurusan Teknik Perkapalan Politeknik Negeri Bengalis.

\section{Sosialisasi dan Pembekalan kepada mitra}

Setelah mesin di produksi maka dilakukan sosialisais dan pembekalan terhadap penguna terhadap alat yg dihasilkan, masukan dan kesempurnaan alat dari penguna atau mitra dapat membantu kami dalam penyempurnaan alat ini lebih baik lagi.

\section{HASIL DAN PEMBAHASAN}

\section{Bahan Cuci Mobile Hand Washer (MHW)}

Adapun bahan yang digunakan dalam pembuatan adalah:

1. Besi Stanles $2 \times 3$ Inci

2. Plat stanlees $2 \mathrm{~mm}$

3. Westafel

4. Pinguin Penampung air kapasitas $250 \mathrm{~L}$

5. Cran Air

6. Pipa PCV $3 / 4$

7. Elbow, $\mathrm{T}$, valve pembuagan

8. Lem Pipa PCV

9. Roda

10. Paku kling 
INTEGRITAS : Jurnal Pengabdian

Vol 4, No 2, Desember 2020

ISSN 2580 - 7978 (cetak) ISSN 2615 - 0794 (online)

11. Selang Gas

12. Sabun

\section{Alat}

1. Mesin las

2. Gerenda

3. Elektroda

4. Tang

5. Obeng

6. Palu

7. Solder

8. Siku-siku

9. Bor tangan listrik

\section{Desain Alat Cuci Tangan Portable}

Alat pencuci tangan dibuat sesuai tujuan yang diberi nama protable hand washer (PHW) semi otomatis Alat ini memiliki tiga bagian utama yaitu rangka utama alat, tangki penyimpanan air dan empat buah westafel tempat pencuci tangan. Rangka utama alat berfungsi untuk menopang tangki, westafel dengan sistem pembuangan mengunakan pipa PCV 3/4, alat ini mudah di pindahkan karena di lengkapai dengan roda untuk pengisian tangki dan pemindahan lokasi tempat keramaian.

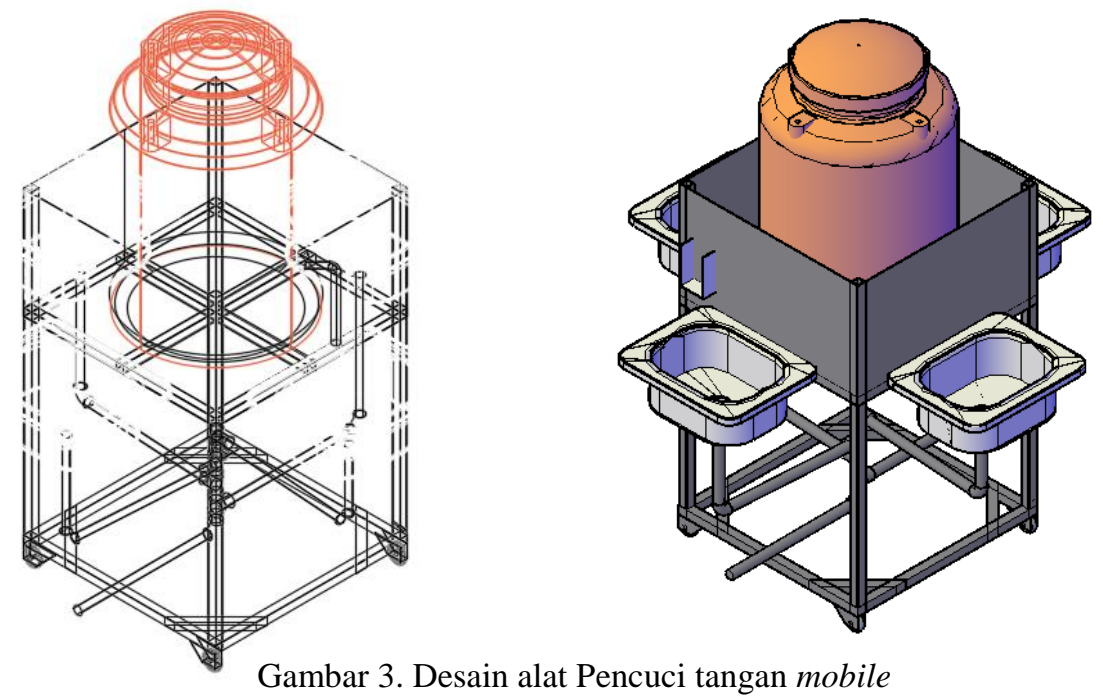


INTEGRITAS : Jurnal Pengabdian

Vol 4, No 2, Desember 2020

ISSN 2580 - 7978 (cetak) ISSN 2615 - 0794 (online)

Adapun diskirpsi produk cuci tangan portable adalah sebagai berikut:

1. Kapasitas tabung (torrent) lebih besar yaitu 250 liter

2. Alat ini mobile sehingga bisa di posisikan di tempat keramaiayan

3. Kapasitas wetafel 4 buah sehingga masyarakat yang ingin mencuci tangan tidak perlu mengantri terlalu lama

4. Di buat dengan bahan stanless sehingga tidak cepat korosif apabila di letakkan di luar ruangan.

5. Dilengkapi sistem semi otomatis dengan pedal pemijak sehingga penguna tidak perlu menyentuh kran dan botol sabun.

\section{Perakitan Alat Cuci Tangan Portable}

a. Pemotongan besi sesuai dengan ukuran torrent

b. Penyambungan alat

c. Perakitan alat

d. Sistem pembungan air

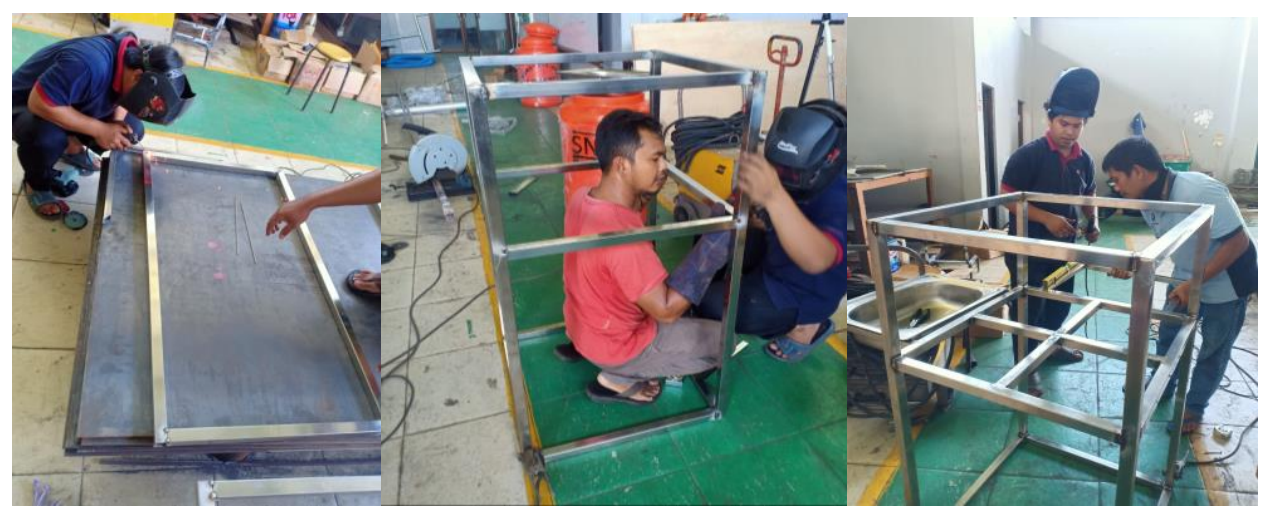

Gambar 4. Proses Perakitan Alat Mobile Hand Washer 


\section{INTEGRITAS : Jurnal Pengabdian}

Vol 4, No 2, Desember 2020

ISSN 2580 - 7978 (cetak) ISSN 2615 - 0794 (online)

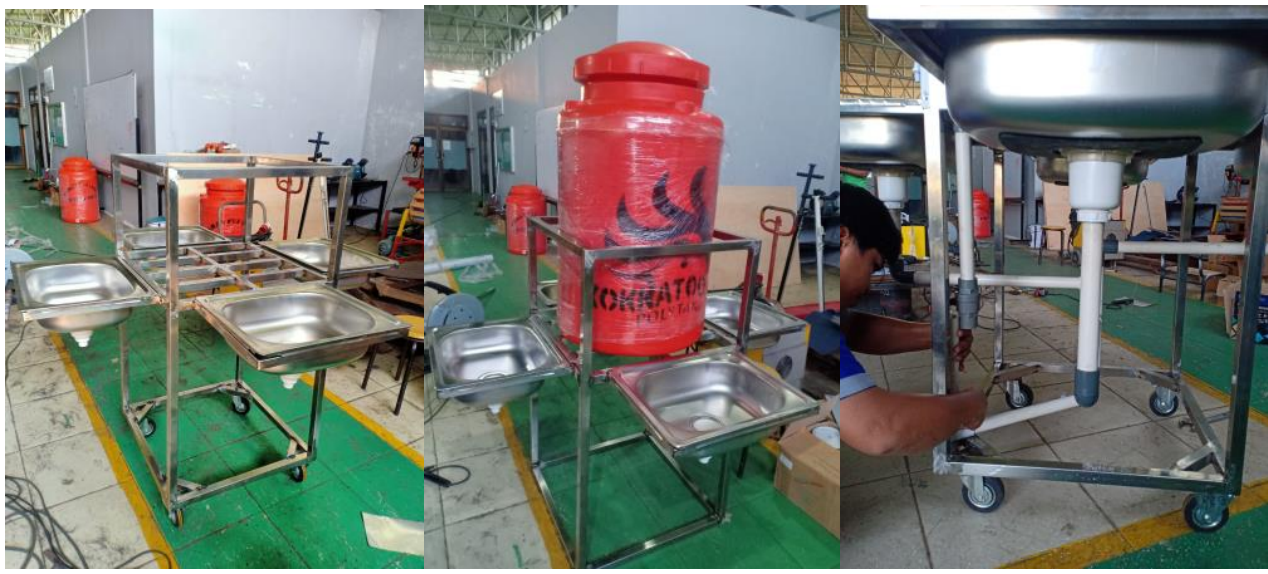

Gambar 5. Proses Perakitan Alat Mobile Hand Washer

\section{Penyerahan kepada Mitra Rumah Ibadah}

Potensi penularan virus atau bakteri sangat mungkin terjadi di tempat umum, tak terkecuali masjid atau mushala. Oleh Sebab itu Politeknik Negeri Bengkalis kembali menunjukkan kepedulian dan keseriusan dalam mencegah penularan Covid-19 tahun ini. Melalui Pusat Penelitian dan Pengabdian masyarakat (P3M) mengembangkan alat cuci tangan mobile di tengah wabah covid. Pengembangan alat cuci tangan Porttable, Di tengah masa wabah corona atau Covid-19 ini menjaga kebersihan menjadi yang paling utama untuk memutus mata rantai penularan virus. "Keberadaan alat ini bersifat mencegah dan bukan mengobati,"

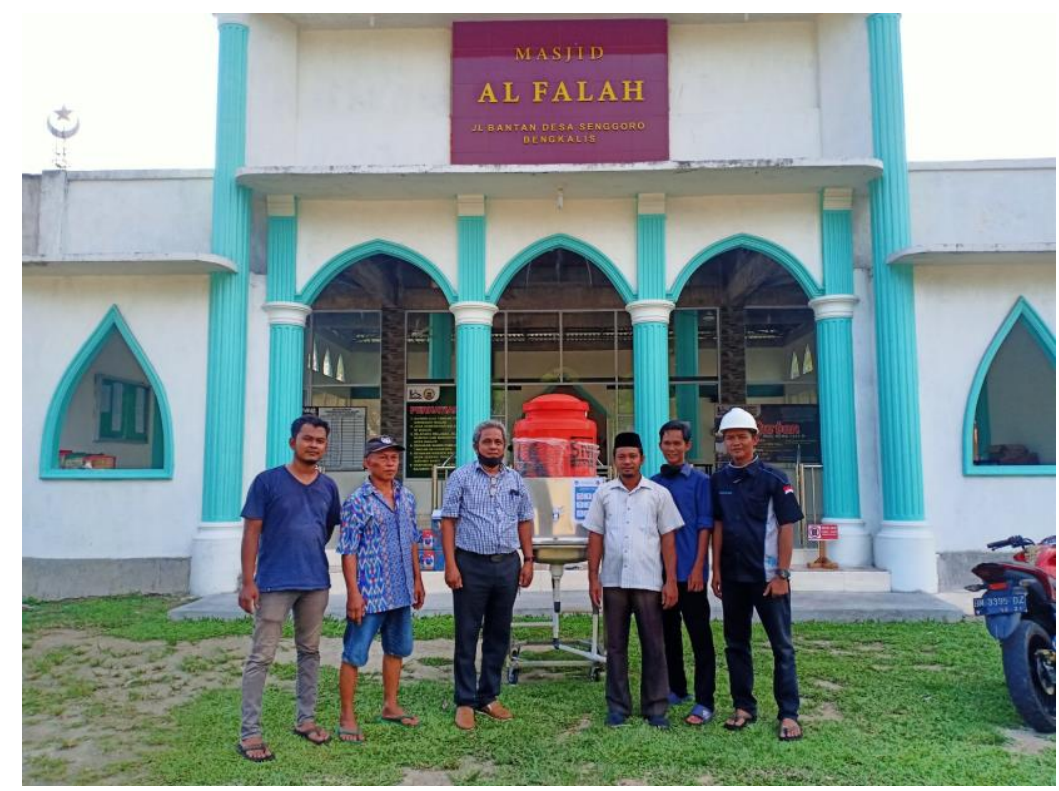

Gambar 6. Penyerahan Alat Cuci tangan kepada Pengurus Mesjid Al-Falah 


\section{INTEGRITAS : Jurnal Pengabdian}

Vol 4, No 2, Desember 2020

ISSN 2580 - 7978 (cetak) ISSN 2615 - 0794 (online)

Himbawan dari Pemerintah kepada pengurus mesjid maka salah satu protokol kesehatan pengurus mesjid harus menyediakan alat cuci tangan lengkap dengan sabun atau cairan disinfektan, oleh sebab itu rumah ibadah sangat membutuhkan alat cuci tangan tersebut. Penyerahan alat cuci tangan di lakukan oleh Ketua P3M bapak Akmal, Indra, S.Pd, MT kepada pengurus Mesjid Al-Falah Desa Senggoro di Jl. Bantan Samping MAKODIM 0303 Bengkalis yang diterima langsung oleh Ketua Mesjid Bapak Ustadz Syamsul, S.Pt. Penyerahan alat cuci tangan portabel ini, sebagai mengkampanyekan gerakan cuci tangan secara terus menerus, sekaligus sebagai upaya pencegahan penyebaran virus Corona

\section{Pengunaan alat oleh Mitra}

Alat cuci tangan Porttable digunakan oleh jemaah ketika akan memasuki dan keluar dari mesjid yang dilakukan pada sholat 5 waktu, sholat jumat, dan sholat idul fitri. Hal ini merupakan salah satu protokol wajib kesehatan yang harus dilaksanakan selain membawa sajadah sendiri, mengunakan masker, dan sosial distancing untuk memutus rantai penyebaran corona di rumah ibadah.

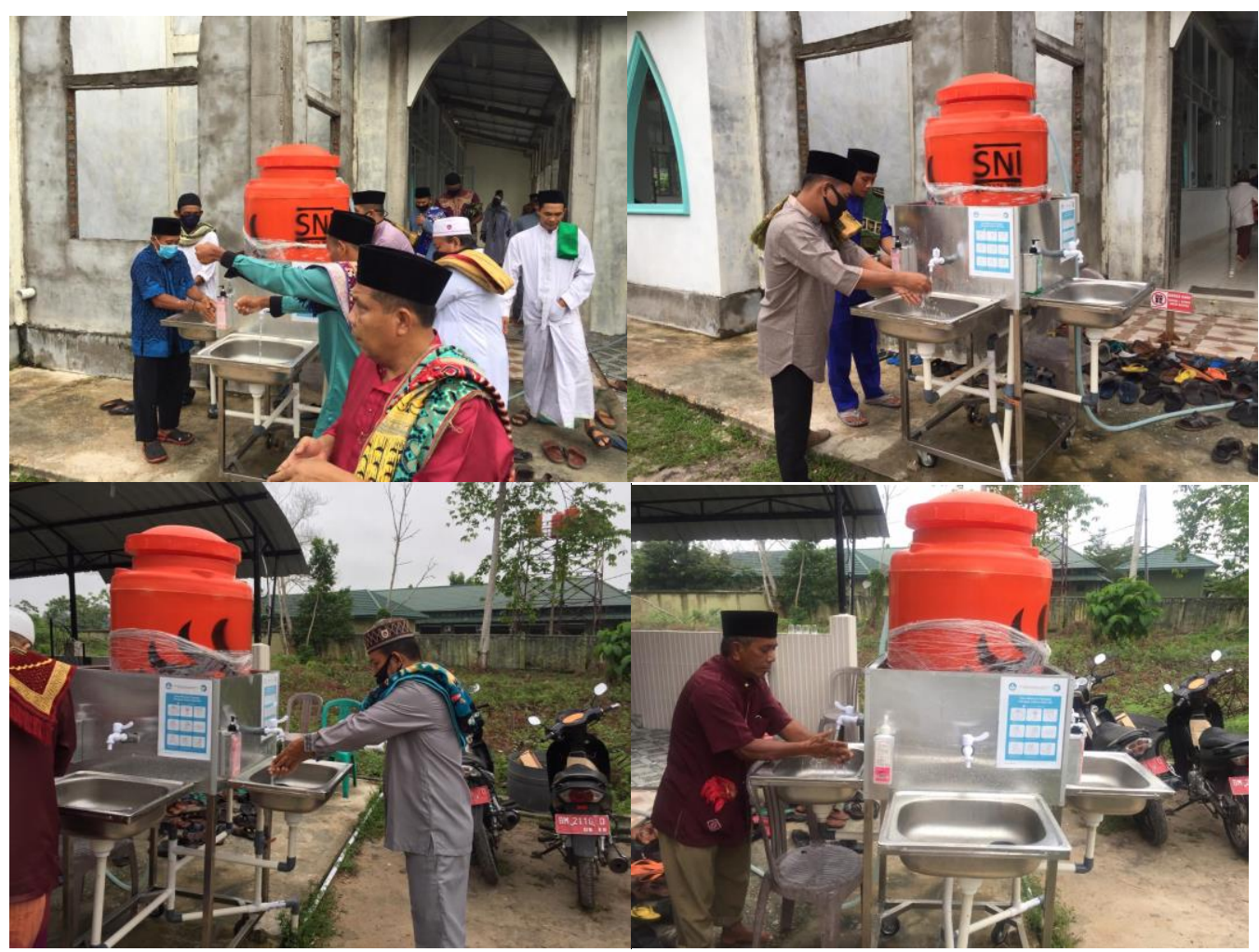

Gambar 7. Pemanfaatan Alat Cuci tangan portable oleh mitra Mesjid Al-Falah 
INTEGRITAS : Jurnal Pengabdian

Vol 4, No 2, Desember 2020

ISSN 2580 - 7978 (cetak) ISSN 2615 - 0794 (online)

Dengan patuhnya jamaah terhadap himbauan dari pemerintah dan pengurus mesjid terhadap protokol kesehatan alhamdulillah masyarakat di lingkungan Dusun 4 dengan jumlah jamaah 600 orang belum adanya yang terideksi positif terjangkit virus corona. Semoga masyarakat selalu menerapkan pola hidup bersih dan kita semua terhidar dari segala macam wabah penyakit.

\section{KESIMPULAN}

Adapun kesimpulan dari produk alat cuci tangan portable adalah sebagai berikut:

1. Alat cuci tangan ini berkapasitas 250 liter sehingga mitra tidak selalu mengisi air kedalam tanki.

2. Kapsitas westafle berjumlah 4 unit sehingga masyarakat atau jamaah tidak perlu mengantri terlalu lama.

3. Alat cuci tangan ini mudah di pindahkan karena di pasang roda yang mudah di gerakkan sesuai lokasi yang diinginkan.

\section{UCAPAN TERIMA KASIH}

Ucapan terimakasih kepada pimpinan Politeknik Negeri Bengkalis yang telah mendanai kegiatan pengabdian penugasan pada masa pandemi COVID -19 melalui skema PNBP oleh lembaga Penelitian dan Pengabdian, selain itu terimakasih kamu sampai pengurus Mesjid Al-Falah Desa Senggoro Kecamatan Bengkalis yang telah membantu terlaksananya kegiatan ini serta semua pihak yang terlibat.

\section{DAFTAR PUSTAKA}

Safrizal ZA, dkk, 2020. Pedoman Umum Menghadapi COVID19 bagi Pemerintah daerah Tim Kerjasama Kementiran dalam Negeri Untuk Dukungan Gugus Tugas.

Panduan Mencegah Virus Corona, Cara Cuci Tangan yang Benar Kompas.com 14/03/2020, 20:07 WIB judul "Panduan Mencegah Virus Corona, Cara Cuci Tangan yang Benar".

https://www.kompas.com/sains/read/2020/03/14/200700023/panduan-mencegahvirus-corona-cara-cuci-tangan-yang-benar. 
INTEGRITAS : Jurnal Pengabdian

Vol 4, No 2, Desember 2020

ISSN 2580 - 7978 (cetak) ISSN 2615 - 0794 (online)

https://www.liputan6.com/bola/read/4219578/tips-mencuci-tangan-yang-benarmenurut-who-demi-cegah-virus-corona-covid-19\# 